\title{
The Problem of Democratic Dirty Hands: Citizen Complicity, Responsibility, and Guilt
}

DOI:

10.1093/monist/onx039

\section{Document Version}

Accepted author manuscript

Link to publication record in Manchester Research Explorer

\section{Citation for published version (APA):}

De Wijze, S. (2018). The Problem of Democratic Dirty Hands: Citizen Complicity, Responsibility, and Guilt. The Monist, 101(2). https://doi.org/10.1093/monist/onx039

\section{Published in:}

The Monist

\section{Citing this paper}

Please note that where the full-text provided on Manchester Research Explorer is the Author Accepted Manuscript or Proof version this may differ from the final Published version. If citing, it is advised that you check and use the publisher's definitive version.

\section{General rights}

Copyright and moral rights for the publications made accessible in the Research Explorer are retained by the authors and/or other copyright owners and it is a condition of accessing publications that users recognise and abide by the legal requirements associated with these rights.

\section{Takedown policy}

If you believe that this document breaches copyright please refer to the University of Manchester's Takedown Procedures [http://man.ac.uk/04Y6Bo] or contact uml.scholarlycommunications@manchester.ac.uk providing relevant details, so we can investigate your claim.

\section{OPEN ACCESS}


The Problem of Democratic Dirty Hands: Citizen Complicity, Responsibility, and Guilt

Stephen de Wijze

MANCEPT

Politics, University of Manchester 
'Politics is an arena where the best is the enemy of the good, where we licence our agents to pursue the good, and where they can succeed only if they operate partly beyond our ken and our control.' (Hollis) ${ }^{1}$

Because democratic officials are supposed to act with the consent of citizens, they face a further dilemma. If they gain that consent, they are not uniquely guilty in the way the problem in its traditional form presumes. If they act without that consent, they not only commit a further wrong (a violation of the democratic process), but they also cast doubt on the justifiability of the decision itself. They undermine some of the conditions of moral discourse that are necessary to judge the morality of any decision in a democracy.

(Thompson) $^{2}$

Since Michael Walzer's seminal article 'Political Action: the Problem of Dirty Hands' ${ }^{3}$, there has been considerable debate over whether 'dirty hands' (DH) actions are indeed possible. A great deal of ink has been spilled to demonstrate either that such scenarios are possible and an unavoidable part of our moral reality, or merely confused and incoherent moral thinking. The focus in this paper is on a related criticism of DH scenarios; namely, that democratic governance with its core normative values renders the idea of 'democratic dirty hands' (DDH) oxymoronic and hence incoherent. As the quote from Thompson above points out, democratic politicians dirtying their hands, violate the deep values of democratic governance fatally undermining both the justifiability and the moral discourse by which we ought to judge such political actions. ${ }^{4}$ Consequently, even if the peculiar and sui generis claims of those who argue for DH scenarios can be justified, they become incoherent when specifically applied to democratic politicians operating under a rule of law. The paper also argues, in agreement with Thompson and others, that while this criticism is not in fact justified, it does bring to light an important and under-recognized consequence of dirty hands action in democratic societies, that the moral difficulties faced by democratic leaders in dirty hands contexts are in fact shared by the democratic public. In addition, however, the paper tries to show why the involvement of democratic process and citizenry in DH actions does not make DH incoherent. This paper, then, explores this important yet under theorised problem of $\mathrm{DDH}^{5}$. Specifically, it argues that DDH are indeed possible, inevitable and endorsed by democratic citizens when they elect their politicians. Furthermore, the paper also examines the moral implications for democratic citizens when their elected representatives dirty their hands for their benefit.

I set out the paper as follows. Section 1 outlines what I take to be the core claims that underlie standard accounts of the problem of DH. In section 2, I briefly set out what I take to be the minimal conditions a form of governance must meet in order to be democratic. In section 3 , I outline, evaluate and reject three criticisms raised against the very possibility of DDH. In section 4, I explore a number of important moral implications for citizens given that DDH are conceptually possible and unavoidable. The issues concern the complicity of democratic citizens, the degree of their accountability, and the price they ought to pay for benefiting from DDH actions.

\section{The problem of DH}

The problem of DH is a specific kind of justified unavoidable moral wrongdoing. ${ }^{6}$ This is a deeply controversial claim firmly rejected by a wide range of moral theorists from both the deontological and consequentialist perspectives. The common charge is that the very notion that we can do wrong in order to do right reveals, at best, a deep confusion and misunderstanding of moral theory. ${ }^{7}$ Advocates of this view argue that an action cannot be morally obligatory yet simultaneously also morally impermissible. This is an incoherent assertion and arises from deeply muddled (and for some dangerous ${ }^{8}$ ) thinking. Yet for those who argue for the possibility and unavoidability of DH scenarios, this dismissal is unacceptably reductionist and fails to do justice to our complex moral reality. It fails to recognise that good persons sometimes face intractable moral conflicts which bring with them a tragic element and unavoidable moral pollution. ${ }^{9}$ Consequently, advocates of DH scenarios have sought to show that such phenomena are indeed coherent moral scenarios and that it is possible to offer necessary and sufficient conditions for 
identifying them. These conditions enable us to distinguish DH actions from those which are simply immoral or manifestations of other forms of unavoidable moral conflicts.

It is difficult to provide a simple and uncontroversial characterization of $\mathrm{DH}$ position as the literature offers a number of different albeit overlapping accounts. ${ }^{10}$ While DH scenarios are a sui generis type of intractable moral conflict, there is disagreement about their form, genesis, and the necessary conditions required for them to obtain. Some view the problem as principally the Machiavellian 'means/ends problem' in politics. ${ }^{11}$ Politicians, statespersons, and essentially anyone who wishes to achieve worthwhile and noble goals in politics (or other forms of public office) need to understand that occasionally it will be necessary to use immoral means. This is what Machiavelli means when he states that 'when the act accuses the result excuses'. ${ }^{12}$ In politics, 'the best is the enemy of the good'13 and a proper concern and balance with respect to both principles and consequences are needed for successful and responsible political agents. Furthermore, advocates of the 'means/ends problem' point to the tension between what is required qua politicians given their special duties and obligations, and what is prohibited in private life in terms of the generic demands of morality. In short, politicians will at times unavoidably face an irresolvable conflict between the normative demands of their public duties and those of their private lives. ${ }^{14}$

A related but different approach is to understand the notion of $\mathrm{DH}$ as arising from an unavoidable clash between consequentialist and deontological moral duties. ${ }^{15}$ In this account, DH scenarios occur in both public and private domains (albeit more frequently in the political domain) since the problem arises due to the different emphases of these ethical approaches: deontology with the principles and intentions guiding actions while consequentialism focusing on consequences. This clash is what Walzer seeks to highlight in his (in)famous 'Ticking Bomb' scenario. ${ }^{16}$ Faced with such a clash between upholding principles and minimizing the terrible consequences of not acting, the politician has no morally clean course of action. ${ }^{17}$

A third way of accounting for DH scenarios is by rejecting a monist account of moral values, one which underlies most versions of consequentialist and deontological moral theories. A pluralist account of moral value explains why DH scenarios inevitably arise in all domains of our lives. ${ }^{18}$ If we cherish different values (such as liberty, equality, justice, and sympathy), and agree that they cannot be hierarchically ordered or subsumed under one supreme value (eg. justice or utility), then intractable conflicts are unavoidable and a persistent part of our moral experiences. Any action taken in such conflict situations will violate a cherished value leaving a moral remainder to take into account.

Finally, a useful way to think about DH scenarios is by attempting to answer the following question; is it possible to have an action or project which is at once (1) justified, even obligatory, but also (2) nonetheless somehow wrong and shameful ${ }^{19}$ This approach enables the incorporation of insights from a number of characterizations of DH. It provides a way of demonstrating that such scenarios are conceptually possible and that we can provide a set of necessary and sufficient conditions for identifying them. However, as I pointed out above, to argue over these specific issues is not the focus of this essay. I will take the points I outline below as largely agreed upon among dirty hands theorists. I also intend the necessary conditions set out below to be sufficiently general to avoid offering my own particular view. The hope is that all dirty hands theorists will feel able to endorse them even if they think they are incomplete. I, consequently, will stipulate six necessary conditions that set out the sui generis nature of DH scenarios. If the reader is skeptical of the very idea of DH, my hope here is that a provisional acceptance will enable some sympathy for the problem of DDH and why it may be a part of our moral reality.

All DH scenarios, then, involve the following necessary conditions:

1. They occur only in situations of unavoidable genuine moral conflict.

2. They contain a justified violation of persons or cherished values.

3. They give rise to a moral residue or remainder.

4. The primary motivations to commit a justified moral violation are powerful moral considerations.

5. The moral violation seeks to bring about the lesser evil.

6. They arise more frequently and with greater urgency and import in the political domain. 
The above list is not complete and the six claims need much commentary but they will suffice for our purposes here. ${ }^{20}$ It is important to note that the above conditions are silent about why DH conflicts arise and take no stand on the issue of whether we should endorse value monism or pluralism. DH scenarios, then, are those unfortunate, difficult and sometimes tragic moral situations, where no matter how the agent (committee, government, electorate) acts there can be no avoiding the violation of persons and/or violation of a cherished principle. ${ }^{21}$ Genuine DH scenarios lie on a continuum ranging from those involving relatively minor moral infractions to cases where there is the commission of terrible moral crimes. ${ }^{22}$ Fortunately, the most serious cases, which are usually found in politics, are relatively rare, but they are often offered as paradigm examples of $\mathrm{DH}$ as they dramatically highlight this important part of our moral reality. ${ }^{23}$

\section{Democratic governance - core values and conditions}

As already mentioned, the problem of DH faces many criticisms: conceptual, logical, political, ethical, and pragmatic. However, recent critiques focus specifically on DDH and its specific issues. The core charge is that that those who argue for the possibility of DDH scenarios 'fail to appreciate the difference that democracy makes'. ${ }^{24}$ However, before we can assess this claim we need clarity on what are the core values and conditions of a genuine democratic society. Any analysis of the possibility or otherwise of DDH rests heavily on a particular understanding of what a properly functioning democratic governance entails, and more specifically, how the normative values underlying this form of governance place constraints on moral (and legal) actions. While this is not the place to engage in a wide-ranging account of the meaning of the term 'democracy', a set of uncontroversial minimal conditions of this concept is necessary. These conditions need to remain agnostic about the particular type of democracy adopted, be it aggregative or deliberative, representative or direct, procedural or substantive.

With this aim in mind, I contend that a properly constituted democracy whatever version or particular manifestation it finally adopts) must meet the following minimal necessary conditions:

1. Political legitimacy/power is always a derived authority given by way of delegation from the citizens. This transfer occurs through some form of regularly recurring assessment of citizen preferences. Democratic governance does not recognize any other basis for political authority other than the will of citizens.

2. The right to vote in a genuine democratic polity applies to all competent adults. ${ }^{25}$

3. A rule of law underpins democratic societies, which applies equally to all citizens.

4. Since citizens contingently confer political power, politicians always remain ultimately accountable to them for their actions and decisions. Politicians are required to be open and forthcoming about their intentions, plans and views, so that citizens can choose their politicians based on accurate information about past actions and future intentions. This enables a fiduciary relationship between citizens and politicians where the former use their institutional power in a manner consistent with their stated promises, best judgments, goodwill and integrity. ${ }^{26}$

I shall assume that that the above minimal conditions, whatever the particular variations concerning electoral process or nature of representative, are widely accepted. To achieve this consensus, I have deliberately not included the controversial claim that democracy is a good in itself. Furthermore, I have not claimed how, or by what means, politicians are accountable to citizens, as different democracies do this in different ways and which is correct is open to considerable debate. ${ }^{27}$ Most importantly for my concerns here, I have not claimed that democracy demands a particular approach to doing politics, no matter what the circumstances. As we will see, the rejection of DDH rests in large part on a view about what a genuine functioning democracy requires of its politicians and citizens. It is my contention that this view, combined with a number of misunderstandings about the essence of $\mathrm{DH}$, leads to their erroneous claim that DDH are not possible.

\section{The problem of DDH}

The recent scholarship concerned with DDH is small and divided into two distinct groups. The first is that of strident critics who reject the very possibility of DDH. ${ }^{28}$ The second group accepts the 
possibility of DDH scenarios, but believes that the democratic context makes a very important difference to our way of understanding the concept itself, specifically with regard to the issues of political accountability and the extent and scope of moral pollution. ${ }^{29}$ In addressing these issues, I first outline the specific problems raised by critics of DDH and then explore their plausibility, strength and possible responses.

\subsection{Democratic governance and the standard DH account}

The analysis of the DH problem has historically focused on the actions of kings and princes who transgressed the conventional morality of their time for reasons of state. ${ }^{30}$ More recently, the spotlight has shifted to the dramatic problems faced by revolutionaries, typically lone actors or small groups of militants, making hard choices in the face of terrible dilemmas while resisting oppression. We find excellent examples of this kind in contemporary literature, such as Sartre's 'Dirty Hands', Camus' 'Just Assassins' and Brecht's 'The Measures Taken'. ${ }^{31}$ However, this focus on kings and revolutionaries, the 'heroic' or 'aristocratic' models interpretation of DH, masks the fact that underpinning genuine and properly functioning democratic governance are fundamental values which prohibit politicians or any public servants from getting $\mathrm{DH}^{32}$ By dirtying their hands, democratic politicians not only violate conventional (private) morality in the defence of the public good, but also commit a further wrong that involves the willing violation of democratic principles from which they obtain their moral authority and legitimacy. Furthermore, this raises the question of whether democratic politicians who dirty their hands are solely responsible for the moral violation they commit. The issue of possible citizen complicity becomes apposite. If citizens have given implicit consent for DDH then they too are complicit with the moral wrongdoing carried out in their name. In short, DDH raises two pressing issues not sufficiently explored by the standard model of $\mathrm{DH}$.

The first issue concerns the conceptual question of whether DDH are indeed possible in a properly functioning democracy. Shugarman and Sutherland argue that the very idea of DDH is oxymoronic; a contradiction in terms such as claiming the existence of 'free slaves'. ${ }^{33}$ A democratic politician who undermines the democratic values, those which make it possible to assess the normative status of political actions, is doing wrong simpliciter. What is more, an understanding of DH based on the intentions of a lone agent facing an unavoidable moral conflict distorts the essential nature of democratic politics. ${ }^{34}$ It fails to recognize that all democratic political actions ought to occur under a constitution and rule of law. If there is a need for deceit or manipulation, or the use of violence to ensure the common good, then this needs to be approved and authorized in advance through democratic procedures. For example, acceptable undercover deception by the police to apprehend criminals requires prior sanctioning and regulation by the appropriate democratic institutions. ${ }^{35}$ Any deception beyond this would not be a case of DH but simply a destructive and unjustifiably immoral (and illegal) act. Consequently, the idea of a lone actor breaking the laws or committing moral violations for the public good undermines the very essence of democratic governance, rendering the notion of DDH incoherent.

The second pressing issue arises if we accept that DDH are indeed possible. It raises difficult questions concerning the role and accountability of citizens in these unique scenarios. How, if at all, are citizens complicit with this wrongdoing? Do the citizens of a democratic society bear the same or less responsibility and moral opprobrium as their politicians? Do politicians have implicit licence to dirty their hands when it is necessary to protect citizens from the great social and natural evils, a licence for which citizens are ultimately responsible? And, if no such licence is given, is there still a moral cost to democratic citizens who benefit from the moral wrongdoing of politicians acting in their name? These and other related questions are the focus of the remainder of this paper.

\subsection{The Impossibility of DDH -3 erroneous arguments}

Among the arguments against the existence of DH, one set focuses specifically on its impossibility within a properly functioning democratic society. ${ }^{36}$ The two most forceful proponents of this view are 
Shugarman and Sutherland, who object to DDH on three grounds. ${ }^{37}$ They argue that the notion of DH cannot apply within democracies for three reasons.

1. The heroic lone actor assumption that underpins the standard account of DH is antithetical to proper democratic governance.

2. DH theorists erroneously assume that such scenarios are the staple of politics.

3. Democratic governance requires a new form of politics, which make DH scenarios preventable and hence unjustifiable.

If any of the three claims above were correct, this would fatally undermine the very possibility of DDH. However, all three arguments are unsuccessful on closer examination. They either commit the 'Straw Man Fallacy' or erroneously assume that democracies produce a benign form of politics where there is always an unalloyed moral option available for politicians to choose.

\subsubsection{The 'Lone Actor' critique}

Both Shugarman and Sutherland rightly note that in the DH literature, the scenarios explored usually focus on the lone politician trapped in a moral dilemma making difficult, wise, and heroic choices for the public good. This emphasis may be appropriate for some forms of governance but it pays insufficient heed to the constitution and rule of law that underpins democratic authority. Decisions made in a democracy are almost always group decisions, and not based on the whims or preferences of a solitary leader. Furthermore, the very notion of a 'lone actor' making sound judgments about when to violate moral principles (including the very principles of democracy) is illusory. Lone actors are very unlikely to bring about the desired 'lowest-cost sacrifices' since individual judgment is often unreliable, especially in situations of considerable uncertainty and challenging time constraints. Democracy is a better form of governance precisely because it requires 'retrospective-deliberative processes' that set out rules for how politicians ought to respond to challenges in the future. Political institutions set up clear lines of collective political responsibility within the public structures and the processes of the state. ${ }^{38}$ This provides a more reliable and careful set of public judgments, one no lone actor could match no matter how talented.

However, it is an error to assume that lone actor examples are incompatible with other possible forms of decision-making. This assumption over-simplifies the analysis of whether a conceptual space exists for this unique moral phenomenon. The idea of lone action here does not exclude the possibility, or even prevalence, of decision making by groups or committees or the electorate at large via a referendum or general election. Rather, it acknowledges that emergencies require quick decisions and democracies elect one person to make the final decision and accept the responsibility for doing so. What is different is that such decisions are retrospectively subject to scrutiny and need to be justified to the public. Citizens will ultimately pass judgement on these actions through the ballot box, and in extreme cases punish politicians for any wrongdoing.

\subsubsection{The 'staple of politics' critique}

Sutherland and Shugarman claim that those who argue for the possibility of DH are also wedded to the erroneous view that such scenarios are 'the staple of politics' or that they capture the 'important aspects, or the heart, of politics'. ${ }^{39}$ However, most democratic politics involve the allocation of moderately scare resources, adherence to rule of law, negotiations and compromise. It is a far cry from the violence and conflict that plagued Machiavelli's princes.

To insist that DH theorists conceive the terrain of politics as consisting of mostly DH scenarios is simply false. These scenarios are relatively rare cases of one form of unavoidable moral wrongdoing. While DH scenarios are rare, they do nonetheless arise in all spheres of our lives, and they are more frequent and serious in politics. However, for an event to occur more frequently does not entail that it constitutes the bulk or majority of its companion events. ${ }^{40} \mathrm{DH}$ scenarios are neither the staple of politics nor even the dominant mode of politics in democratic political activity. In fact, the number of severe genuine cases of DH in politics should be relatively infrequent in a fully functioning democracy. ${ }^{41}$ 
Sutherland and Shugarman reject the very idea of DDH because they argue that democracies function in a distinctive and unique way, which creates a wholly different kind of politics. Shugarman chides DH theorists for treating 'politics as if it has changed little from the lawless, embattled atmosphere of Machiavelli's Italy'. ${ }^{42}$ As a result, they 'slide easily and disturbingly back and forth between conditions and principles of authoritarian rule on the one hand and democracy on the other'. ${ }^{43}$ However, this accusation has no basis in fact. DH theorists do not reject deliberation, persuasion and compromise as preferable to coercion when possible. Rather, they explore those special circumstances when agents face incompossible moral oughts, which leave no morally cost free option. By claiming that DDH is a contradiction in terms, Shugarman and Sutherland reject the possibility of irresolvable moral conflicts. They reject a tragic view of politics where sometimes it is impossible to achieve good and noble ends without using morally dubious means. Hampshire, drawing on the insights of Machiavelli, argues that in politics we routinely and unavoidably experience shabby compromises, necessary disownings, deceit, ruthless manipulation and violence. He describes this sphere of human interaction as a place of 'experience' characterized by the

idea of guilty knowledge and the expectation of unavoidable squalor and imperfection, of necessary disappointments and mixed results, of half success and half failure. A person of experience comes to expect that her usual choice will be the lesser of two or more evils. ${ }^{44}$

This view of politics, one that DH theorists embrace, obtains for all systems of governance. Democracy cannot avoid this kind of tragic situation; it can only seek to mitigate its effects.

Democratic politicians, then, sometimes face situations that require an urgent response (preventing wide-ranging and open consultation) and where the only effective choices will not be morally (or legally) satisfactory. In such situations, politicians will need to violate democratic values to effectively combat a serious danger to the state and its citizens and ensure the future continuation of the society as a free and fully functioning democracy. Here we experience the paradox of DDH. In some situations, democratic politicians will be duty bound to employ undemocratic and immoral actions to protect the very system of government that rejects these actions as immoral and illegal. However, protecting citizens from dangers to their lives is the politician's primary duty in tandem with protecting and preserving the democratic system. When both duties are incompossible, the problem of DH arises. To argue, as Sutherland does, that when facing such situations democratic politicians always have a higher and prior moral duty to not bypass or corrupt the democratic process of deliberation and disclosure, seriously and dangerously misunderstands the nature of politics and the challenges that will unavoidably arise. ${ }^{45}$

Consequently, we can dismiss all three claims arguing for the impossibility of DDH as serious misunderstandings of the core conditions of DH or as based on a naïve view of politics. Democracies, like every other form of governance, will need to respond to morally dilemmatic situations and, at times, this will necessitate a violation of cherished democratic principles. Politicians in a democracy, whether as individuals acting alone or as members of a committee or legislative body, will unavoidably dirty their hands for the best of reasons, and in so doing need to acknowledge their share of moral pollution.

\section{DDH - complicity, moral pollution, and accountability}

Citizens transfer political legitimacy and power in a democracy and this creates a fundamentally different normative context from other forms of governance. In order to understand the implications of this changed normative context, a number of issues need clarification. The first concerns whether citizens are complicit in the dirty actions of their politicians. Second, if they are complicit, are they accountable or co-responsible for the wrongdoing? Are they jointly liable for compensation to the victims? Third, given that politicians act with the authority, and on the behalf, of their citizens, does the 
moral pollution that adheres to them devolve onto citizens? Is the moral pollution of citizens qualitatively and/or quantitatively different from that which adheres to their politicians?

\section{$4.1 \quad$ Complicity}

Persons (or subjects) who live under a dictatorship, or some other fundamentally undemocratic form of governance, are immune (with some exceptions) from moral blame for the actions of their rulers. Citizens in democracies, by contrast, uniquely confer contingent political legitimacy and institutional power onto their elected representatives. This relationship raises the question of whether citizens are complicit with, and hence in part responsible for, the actions of their politicians. Yet it is not clear just how this relationship of complicity manifests itself in a democracy where politicians act autonomously, employing their own judgments.

Generally, an agent is accountable for what she does and not for what others do. However, in some circumstances she may be responsible for how others react to her actions. Two factors inform her degree of responsibility: how she acted and what she could reasonably expect others to do in response. ${ }^{46}$ However, when referring to complicity, the issue is whether an agent can be accountable and 'liable to sanction' ${ }^{47}$ for the wrongful action that obtains through the agency of another person or group ('the principal'). An agent can be complicit in two different ways, either as a 'co-principal' or as an 'accessory'. ${ }^{48}$ The 'co-principal' with the 'principal' directly participates in the constitutive wrongdoing. The 'accessory' gives aid or encouragement to the principal or co-principal thus causally contributing to the constitutive wrongdoing. Common to both kinds of complicit acts is the causal contribution to the constitutive wrongdoing. However, while accessories indirectly contribute to the wrongdoing committed, their action may not in itself involve wrongdoing, or it may be only indirectly a form of wrongdoing by virtue of its contribution to the principal wrongdoing. Complicit acts usually also involve a particular mental attitude such as mens rea. While this state of mind is evident in the actions of principals and co-principals, it is either absent or far more difficult to establish for accessories.

Complicity also exists on a continuum or sliding scale. Co-principals sit at one extreme as partners in the constitutive wrongdoing while at the other end are agents who could lack a guilty mind and whose acts, in some special cases, might not even be causally connected to the wrongdoing committed. ${ }^{49}$ In addition, there are a host of different degrees of complicity depending on how we evaluate the causal distance, the agent's knowledge, and contribution of the accessory's act to the wrongdoing committed.

There are other issues to consider if an agent's actions were indeed complicit with the principal wrongdoing. Does complicity automatically trigger a moral responsibility for causally contributing to the wrongdoing? Did the accessory know, or should she have known, about the actions of the principal at the time of acting? If there is a moral responsibility, what is the extent of moral blame that falls on the accessory? The answer to this question depends on ascertaining the extent of the accessory's causal role in the genesis of the wrongdoing and the degree of wrongdoing involved. Finally, a question that is particularly apt for thinking about the problem of DDH is whether the act of complicity was unavoidable, necessary and, ceteris paribus, the right thing to do. Our answers to such questions will underpin our understanding of both the politician's and citizen's responsibilities and degree of moral pollution (and praise) in cases of DDH.

\subsubsection{The complicity of citizens in a democracy}

With the above basic outline of the notion of complicity, it is reasonable to argue that democratic citizens are either co-principals with or accessories to the wrongful actions of their elected representatives. ${ }^{50}$ However, leaving aside voting in referenda where citizens express their view on a specific question, the democratic process is a complexly mediated one. A vote for a politician need not be an endorsement of her entire bundle of policies. What is more, a democratic politician is not bound legally to follow the wishes of her electors, and at times, it may be necessary and morally right to act contrary to them. ${ }^{51}$ This raises the difficult question of how to understand citizen responsibility and complicity when elected politicians act unjustly. Citizens when electing representatives face the considerable difficulty of trying to make a prospective judgment about whether a candidate would act in terms of the principles they espouse. The very wide range of judgements required of a politician means 
that it is impossible to get assurances on all and every future action, especially cases of unexpected emergencies and unforeseen crises. Even retrospectively, it remains very difficult properly to assess a politician's actions given the complexity of issues involved and the inevitable lack of full information. ${ }^{52}$ These conditions help mitigate citizen responsibility for the immoral actions of their elected representatives, but this does not provide them with immunity

Pasternak rightly points out that identifying the complicity of democratic citizens even in wellfunctioning democracies is not an easy task. ${ }^{53}$ Apart from the complex mediated democratic process, there is the issue of whether the very idea that a democratic group with no formal decision-making procedures can be responsible for its causal collective actions. Furthermore, even if citizens can be collectively accountable, the actions of representatives are not necessarily the actions of the democratic public. Much here depends on what we understand by political representation and how we answer a number of other important questions concerning the relationship between citizens and their representatives. Do citizens have a relationship of representation that reduces the likelihood of their elected officials from engaging in unjust acts or policies? When electing their politicians, could citizens have reasonably foreseen the immoral policies implemented in their name? Could they have prevented them but failed to do so ${ }^{54}$ Therefore, while citizens can be complicit as accessories and co-principals in the immoral actions of their politicians, this responsibility may not apply to every (or even most) unjust policies. What is reasonable to assume is that democratic citizens potentially share responsibility for the actions of their elected leaders and this necessitates a careful exploration of when and to what extent, they are complicit.

How ought citizens to react to the immoral (that is not DH, but simply bad) actions of their elected representatives given their potential complicity? At a minimum, they should seek to remove and punish those politicians who commit immoral acts and replace them with ethical alternatives. This is often an impossible task (at least in the short term) due to the complex nature of contemporary liberal democracies. So when removal is not an option, citizens will need to seek ways of reducing their 'complicity footprint'. ${ }^{55}$ This involves eschewing benefits that might arise from the unjust actions and accepting some responsibility (such as increased taxes) to provide restitution for the ill-treated parties. Good democratic citizens also ought to feel the moral weight of their complicity with immorality and injustice even if they neither could have prevented nor can undo it. Here Beerbohm argues, the appropriate feeling for citizens is 'democratic agent-regret'. This is the feeling that acknowledges that

political institutions can put us in a special relation with those who are unjustifiably affected by it. It reflects the special attitude we have to consequences that we bring about or forms of treatment that we sustain. This attitude makes little sense from an agent-neutral position. It is possible only in individuals who have special concern for their actions... It made possible a conception of democracy that foregrounds our relation of shared liability. ${ }^{56}$

Constraints on space prevent me from exploring the questions associated with democratic complicity in more detail. But the above should suffice to enable a clear analysis of citizen complicity in cases of DDH. If a politician deliberately commits a justified wrong, does this change the way we ought to think about citizen responsibility and guilt for such actions? It is to this issue I turn in the next section.

\subsubsection{Citizen complicity and DDH}

When democratic politicians dirty their hands, they ought only to do so for the benefit of those whom they have a duty to serve and protect. DDH differs from the ordinary moral wrongdoing committed by democratic politicians in that the action or policy was justified, even obligatory, but also nonetheless also wrong and shameful. Citizens' complicity with DDH occurs for many of the same reasons as ordinary democratic complicity. Citizens are potentially and sometimes actually accessories, causally linked to the immorality done in their name, but there are important fundamental differences in the way we ought to think about who is accountable and what ought to be the appropriate moral emotion for such acts.

Let us outline and briefly comment on each of these differences in turn. Firstly, democratic politicians who dirty their hands do so for the best of reasons and commit a justified wrongdoing rather than a wrongdoing simpliciter. Secondly, their motives are laudable and principled: to protect citizens 
from great harms. They did not act to obtain an illegitimate or ill-gotten material gain or political advantage. Thirdly, citizens rightly expect their politicians to protect them from harm even in situations where there is no morally cost free action or policy. We elect politicians in large part to shoulder the burden of making difficult judgments and to accept the moral opprobrium (and praise) which results. It seems reasonable to assume, then, that citizens have given implicit prior consent for DDH when circumstances are such that they are necessary and unavoidable. ${ }^{57}$ Fourthly, the benefit citizens receive from DDH is not one of enrichment but rather that of safety and protection. It is a form of self-defence, which prevents harm and worse when other preferred methods are ineffectual. This difference changes the appropriate moral emotion citizens ought to feel in such situations. In the place of Beerbohm's 'democratic agent regret' citizens (and politicians) ought to feel 'tragic remorse'; the moral emotion that acknowledges the inevitable tragic element of DDH and the moral costs it imposes. ${ }^{58}$ Finally, citizens may need to tolerate, and even support, the secrecy surrounding DDH so that their politicians can act effectively. Successful DDH actions often require a long period where it is necessary to deny or keep secret their existence. ${ }^{59}$

This places citizens in a morally different situation from cases where they need to deal with immoral or corrupt politicians. Citizens need to trust that their politicians dirtied their hands in good faith and that there will be a retrospective accounting for such acts in the fullness of time. This (almost always) requires that citizens accept they will be intentionally deceived about such actions at the time, as those who dirty their hands will necessarily seek to wear clean gloves. Moreover, unlike with democratic complicity where we are concerned with simply immoral or unjust actions, citizens in DDH cases need not publically protest their occurrence. All things considered, they were morally justified acts even if they also resulted in a serious moral violation for which a moral price must ultimately be paid. Since the aim of DDH is to reduce or eliminate harms rather than obtain material or political benefits, citizens need not engage in reducing their 'complicity footprint' by disgorging themselves of this benefit of protection. The security and safety gains that result from DDH are not illegitimate or ill gotten. $^{60}$

\subsection{The moral pollution of politicians and citizens}

DH scenarios involve justified wrongdoing that leaves a moral stain. With DDH, there is the added complication that both politicians and citizens share in the moral opprobrium that arises. What then is the extent of moral dirt that falls on citizens in a democracy who are complicit with the DDH actions? Is it different from that which adheres to the politician who dirtied her hands? One way of

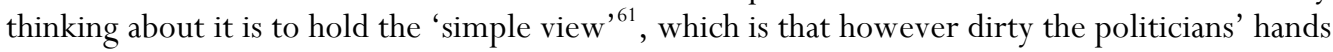
become, it is equally so for citizens. However, this position seems untenable since politicians are autonomous agents, the principals to the wrongdoing. Given this, they rightly draw a greater amount of moral opprobrium since they are closer to the act in two ways: they judge when to act, and only they know 'clearly and completely what is being ordered' ${ }^{62}$ Citizens, therefore, 'escape full but not all complicity in what is done'. ${ }^{63}$ Put another way, the moral responsibility for DDH, and the moral pollution that results from so acting, differs quantitatively but not qualitatively.

Furthermore, there is a 'moral division of labour' where politicians implicitly agree to shoulder a greater share of the blame and moral opprobrium. Their exercise of political agency comes with special powers, duties, responsibilities and privileges. A politician is obligated to use the considerable collective power of the state knowing that in certain circumstances she will be unable to avoid committing a serious moral violation. This leaves her responsible and blameworthy for her DH acts in a special way because she was the agent who willingly agreed to engage in a serious moral violation when necessary. Unlike the citizens who elected her, the politician ought to have a fuller and more direct awareness of what is at stake when she dirties her hands. In addition, the politician knows when acting that she also risks the wellbeing of the democratic system thereby potentially undermining its rationale and core principles. Therefore, she needs to feel the full weight of her moral violations and pay an appropriate price even if paradoxically she was duty bound so to act.

Two further points need stressing here. Firstly, citizens are unable to avoid this moral opprobrium by refusing to vote for representatives or by voting for a politician who failed to gain political office. As part of the democratic polity, citizens remain partly responsible for the actions of even those politicians 
they did not explicitly endorse. A collective responsibility falls equally on all members of the public regardless of their choices or level of political activity. Moreover, unlike cases of ordinary democratic complicity, citizens cannot seek to mitigate the moral pollution by insisting the DDH were not in their name. Because DDH actions essentially involve and are justified by protection of the citizens at large, these actions clearly were in their name, and citizens cannot seek to avoid the moral dirt that these necessary immoral actions created.

\subsection{The accountability of elected representatives}

There is a duty on democratic politicians to justify their actions to citizens. This is no less the case when they dirty their hands. However, to hold politicians to this duty can be very difficult for practical reasons. To achieve their desired results, $\mathrm{DDH}$ actions must partake of the pretence that they are virtuous and above suspicion, and that no moral violations have taken place. Often a politician needs to dirty her hands but wear clean gloves. ${ }^{64}$ Therefore, it is often extremely difficult to ascertain who exactly was responsible for the DH actions and/or the real reasons for why they were necessary. Since successful democratic politicians cannot always practice the virtues of honesty and integrity, they will need to use cunning and guile, which involves the deception of the very citizens to whom they are accountable for such actions. ${ }^{65}$

Given that democratic politicians must ultimately justify their DH actions to citizens, when ought this to be done? There are three possible options that all face serious difficulties. The first and second options, to offer a justification before acting or at the time the action takes place, are almost always unfeasible. While these would be the preferred options from an ethical perspective, DDH typically occur within a timeframe and a scarcity of information that makes these options either impossible or counter-productive. This leaves a final option of justifying DDH as a retrospective exercise. When and how this ought to take place depends on a number of variables. The length of the delay in starting this process depends on the requirement of secrecy and the seriousness of the moral violation. Here the needs of political success and the wellbeing of the democratic system itself clash. Consequently, many cases of retrospective accountability might only responsibly take place long after the action occurred. While it is essential that politicians ultimately account for their DH actions, those responsible may have already left public office by the time it is appropriate to call the politicians to account. This means that some politicians might escape scrutiny for their DH actions. What is more, the victims of DDH who might be eligible for reparations would be subject to a further injustice by having their legitimate claims forgotten or ignored for a long period. These insights point to why citizens in a democracy need a good fiduciary relationship with their politicians. The nature of politics means that politicians who dirty their hands will rarely be called to account. The demands of realpolitik and the complexity of the democratic system would enable politicians to avoid responsibility if they should want to do so. Perhaps the best we can hope is that in the worst cases of DDH, politicians and citizens will both understand the need for and facilitate a public justification in the fullness of time.

The issue of how the retrospective accounting might take place also resists an easy answer. A number of ways of carrying out this exercise are possible, for example, by forcing the relevant politician to justify their past actions to a select committee, or in extreme and serious cases by facing a criminal trial. ${ }^{66}$ Such institutional assessments will need to consider the nature of the threat faced, the options at the time given the information available, the severity of the violation committed, the extent to which democracy has been undermined, as well as the actual effects of the actions taken. Into this difficult mix, it is important to add the character of the politician, her intentions at the time of the action and her specific duties and obligations given her institutional role. With all this in mind, a judgement on the moral (and legal) status of the action will be made along with a judgement on how the society ought to respond to it. This may involve punishment for some (or indeed praise) and a decision as to how this might take place. Punishing a politician (or any agent) for authorizing a justified wrongdoing is controversial even among DH theorists. ${ }^{67}$ Furthermore, if reparations are deemed necessary, who should enforce this?

Despite all the difficulties outlined above, it is necessary for politicians with DDH to be prepared to give an account of why they acted as they did. Furthermore, citizens must hold politicians to account by seeking a justification for their actions. As is clear from the above, there are no easy and simple rules for doing this and at times those guilty of unjustified immoral actions may escape censure 
while, given the complexity and ambiguity of DH situations, those who get genuine DH will sometimes face unfair punishment. Given the complicity of citizens in DDH actions, they may also need to face some penalty for the actions of their politicians, probably, for example, through increased taxes to pay reparation to victims. The rationale and focus of this kind of penalty is to repair the damage done to the democratic system while rehabilitating both politicians and citizens who benefitted from the serious moral violation carried out for the public good.

\section{Conclusion}

There has been a paucity of scholarship on the specific problem of DDH. This paper seeks to address this problem by raising the issues that democratic governance brings to the problem of $\mathrm{DH}$. When focusing on lone individuals in the political domain, the type of governance, democratic or otherwise, played little or no part in the analysis. However, recent contributions to the DH debate have argued that the principles and values underlying democratic governance make DDH an oxymoron. Others have pointed out that core democratic values further complicate our understanding of DDH, which now involves a double violation. Unlike other systems of governance, citizens are complicit with the dirty actions of their elected leaders. They need to acknowledge this, share in the moral burden and contribute to the appropriate restitution. I have argued that critics who maintain, because of the relevance of democratic process and consequently of democratic citizen complicity, that DDH scenarios undermine core democratic principles are incoherent, are in error. They misunderstand the minimal and necessary conditions for getting DH as they do for what constitutes the fundamental values that underlie the wide range of genuine democratic forms of governance. I also argued that with DDH the issues of citizens' complicity, their moral guilt and their accountability become important. Citizens are complicit as accessories and ought to shoulder some of the same moral dirt that devolves on politicians who dirty their hands. However, owing to the moral division of labour, citizens receive the same dirt but a far lesser quantity. Finally, I have argued that politicians need to justify their DDH to citizens even though the practicalities of doing this make it a very difficult and rare event. ${ }^{68}$

\section{References}

Alexander, Larry 2000. 'Deontology at the Threshold'. The San Diego law Review. 37(4): 893-912. Arendt, Hannah. 2003. Responsibility and Judgment. In Jerome Kohn (ed.) New York: Schocken Books.

Anscombe, G.E.M. 1981. 'Modern Moral Philosophy.' In Collected Philosophical Papers. Oxford: Blackwell: 39-40

Archard, D. 2013. 'Dirty hands and Complicity of the Democratic Public.' Ethical Theory and Moral Practice 16: 777-790.

Beck, S. and de Wijze, S. 2015. 'Interrogating the 'Ticking Bomb Scenario': Reassessing the Thought Experiment'. International Journal of Applied Philosophy

https://www.pdcnet.org//pdc/bvdb.nsf/purchase?openform\&fp=ijap\&id=ijap_2015_0999_6_17_4 1 \&onlyautologin=true

Beerbohm, Eric. 2012. In Our Name: The Ethics of Democracy. Princeton: Princeton University Press.

Bellamy, R. 2010. 'Dirty hands and clean gloves: Liberal ideals and real politics.' European Journal of Political Theory 9(4): 412-430.

Berlin, I. 2003. 'The Pursuit of the Ideal' ed. H Hardy. The Crooked Timber of Humanity. London: Pimlico. 
Bok, S. 1999. Lying: Moral Choice in Public and Private Life. New York: Vintage Books.

Brecher, Bob. 2007. Torture and the Ticking Bomb. Oxford: Blackwell Publishing.

Brecht, B. 1977. The Measures Taken and Other Lehrstucke, tr. Stefan Brecht. London: Erye Methuen.

Burke, Edmund. 1774 'Speech to the Electors of Bristol' in The Founder's Constitution at http://presspubs.uchicago.edu/founders/tocs/v1ch13.html

Butt, Daniel . 2007. 'On benefiting from injustice.' Canadian Journal of Philosophy 37 : 129-152.

Camus, A. 2006. 'The Just' trans. Henry Jones in Caligula and other plays. London: Penguin Books.

Coady, C.A.J 1990. 'Messy Morality and the Art of the Possible' in the Proceedings of the Aristotelian Society Supp Vol. 1990, 263.

Coady, C.A.J. 2008 . Messy Morality: the Challenge of Politics. Oxford: Clarendon Press. de Wijze, S. 1994. 'Dirty Hands - Doing Wrong to do Right.' South African Journal Of Philosophy 13(1): 27-33.

de Wijze, S. 1994. 'Dirty Hands - Doing Wrong to do Right.' South African Journal of Philosophy 13(1): 27-33.

de Wijze, S. 1996. 'The real issues concerning dirty hands - a response to Kai Nielsen.' South African Journal of Philosophy 15(4): 149-151.

de Wijze, S. 2003. 'Democracy, trust and the problem of dirty hands.' Philosophy in the Contemporary World 10(1): 37-42.

de Wijze, S. 2005. 'Tragic-Remorse - The Anguish of Dirty Hands', Ethical Theory and Moral Practice 7(5): 453-471.

de Wijze , S. 2012. 'The challenge of a moral politics: Mendus and Coady on politics, integrity and 'dirty hands' in Res Publica, 18/2:89-200

de Wijze, S. 2013. 'Punishing dirty hands - three justifications.' Ethical Theory and Moral Practice. 16(4): 879-897

de Wijze, S. 2014. 'Political Accountability and Moral Pollution: Defending Democratic Dirty Hands' in Biblioteca della libertà, Anno XLIX, n. 209, gennaio-aprile

http://www.centroeinaudi.it/images/abook_file/209online_de\%20Wijze.pdf

Farmer, L. 2007 'Complicity beyond Causality: A Comment'. Criminal Law and Philosophy 1: 151-156.

Gardner, J. 2007. 'Complicity and causality'. Criminal Law and Philosophy, 1: 127-141

Gowans, C.W. 1994. Innocence Lost: An Examination of Inescapable Moral Wrongdoing. Oxford: Oxford University Press.

Hampshire, S. (ed.) 1978 Public and Private Morality. Cambridge: Cambridge University Press.

Hampshire, S. 1989. Innocence and Experience.: Cambridge, Massachusetts: Harvard University Press. 
Haydar, B. \& Øverland, Gerhard. 2014. 'The Normative Implications of Benefiting from Injustice'. Journal of Applied Philosophy. 31/4: 349-362.

Hooker, Brad 2016, 'Rule Consequentialism.' In The Stanford Encyclopedia of Philosophy (Winter 2016 Edition), Edward N. Zalta (ed.), URL:

www.plato.stanford.edu/archives/win2016/entries/consequentialism-rule

Hollis, M. 1982. 'Dirty Hands.' British Journal of Political Science 12 (4): 385-398.

Kutz, C. 2007. 'Causeless complicity'. Criminal Law and Philosophy 1(3): 289-305.

Lepora, C. and Goodin, R.E. 2013. On Complicity and Compromise. Oxford: Oxford University Press. Luban, David. 2006. 'Liberalism, Torture and the Ticking Bomb'. In Karen Greenberg J. (ed.) The Torture Debate in America. New York: Cambridge University Press.

McDonald, M. 2000. 'Hands: Clean and Tied or Dirty and Bloody.' In Paul Rynard and David P. Shugarman (eds.) Cruelty \& Deception: The Controversy Over Dirty Hands in Politics. Ontario: Broadview Press: 187-198.

Machiavelli, N. 1950. The Prince and the Discourses, intro by Max Lerner New York: The Modern Library

Mendus, S. 2009. 'Democratic Dirty Hands'. Paper given at University of York Philosophy Society. Copy on file with author.

Nagel, T. 1978. 'Ruthlessness in Public Life'. In Stuart Hampshire (ed.) Public and Private Morality. Cambridge: Cambridge University Press.

Newey, G. 1997. 'Political Lying: A Defense'. Public Affairs Quarterly 11(2):93-116.

Nielsen, K. 2000. 'There is No Dilemma of Dirty Hands.' Paul Rynard and David P. Shugarman (eds.) Cruelty \& Deception: The Controversy Over Dirty Hands in Politics Ontario: Broadview Press.

Nussbaum, M. 1986. The Fragility of Goodness: Luck and Ethics in Greek Tragedy and Philosophy. Cambridge: Cambridge University Press.

Parrish, John. M. 2007. Paradoxes of Political Ethics: From Dirty Hands to the Invisible Hand. Cambridge: Cambridge University Press.

Pasternak, Avia. 2011. 'The collective responsibility of democratic publics'. Canadian Journal of Philosophy. 41(1):99-124.

Pasternak, Avia. 2014. 'Voluntary Benefits from Wrongdoing' · Journal of Applied Philosophy. 31/4: 377-391.

Paul Rynard, Paul. and Shugarman, David. P. (eds.) 2000. Cruelty \& Deception: The Controversy Over Dirty Hands in Politics. Ontario: Broadview Press.

Sanders, Lynn M. 1997 'Against Deliberation’ Political Theory 25/3: 347-376.

Sartre, Jean-Paul. 1971. Les mains sales : pièce en sept tableaux. Paris: Folio.

Stocker, M. 1990. Plural and Conflicting Values. Oxford: Clarendon Press.

Shklar, Judith. 1984. Ordinary Vices. Cambridge Massachusetts: Harvard University Press. 
Shugarman, D.P. 2000. 'Democratic Dirty Hands?' Paul Rynard and David P. Shugarman (eds.) Cruelty \&Deception: The Controversy Over Dirty Hands in Politics. Ontario: Broadview Press.

Sutherland, S.L. 2000. 'Retrospection and Democracy: Bringing Political Conduct Under the Constitution.' Paul Rynard and David P. Shugarman (eds.) Cruelty \& Deception: The Controversy Over Dirty Hands in Politics. Ontario: Broadview Press.

Thompson, D. 1987. Political Ethics and Public Office. Cambridge Mass.: Harvard University Press.

Thompson, D. 1993. 'Mediated Corruption: the Case of the Keating Five.' American Political Science Review 87: 369-81.

Tillyris, Demetris. 2016. 'After the Standard Dirty Hands Thesis: Towards a Dynamic Account of Dirty Hands in Politics'. Ethical Theory and Moral Practice 19: 161-175.

Tillyris, Demetris. 2015. 'Learning How Not to Be Good': Machiavelli and the Standard Dirty Hands Thesis. Ethical Theory and Moral Practice 18: 61-74.

Walzer, M. 1973. 'Political Action: The Problem of Dirty Hands.' Philosophy \& Public Affairs 2(2): 160180.

Williams, B. 1981. 'Politics and moral character'. Moral Luck. Cambridge: Cambridge University Press.

Yeo, M. 2000. 'Dirty hands in politics: On the one hand, and on the other'. Paul Rynard and David P. Shugarman (eds.) Cruelty \& Deception: The Controversy Over Dirty Hands in Politics. Ontario: Broadview Press.

\section{Endnotes}

${ }^{1}$ Hollis 1982: 396.

${ }^{2}$ Thompson 1987: 11 .

${ }^{3}$ Walzer 1973.

${ }^{4}$ Thompson 1987 does not adopt this strong view on the impossibility of DDH. He points out that politicians in established contemporary democratic societies will unavoidably face situations and moral conflicts that require them to break the rules of conventional morality. Democratic politicians will get $\mathrm{DH}$ when they lie to protect the economy or use manipulation and violence to ensure national security. This is added paradox of DDH that we need to acknowledge and incorporate into our understanding of the concept. Consequently, he seeks to raise the question of how the principles of democracy require us to re-examine our understanding of the standard model since DDH involve the violation of a cherished value and the subversion of democratic principles.

${ }^{5}$ This paper builds on an earlier attempt to explore the nature of DDH. See de Wijze 2014.

6 The possibility of unavoidable moral wrongdoing is not the exclusive claim of DH theorists. Gowans 1994 argues that inescapable moral wrongdoing occurs when specific and important moral obligations to persons clash with universal principles of a Kantian or Utilitarian kind. Gardner 2007 argues that when 
there are proper justifications for wrongdoing, these do not negate or annul the other weighty reasons against so acting. Neither theorist holds these views to be necessarily instances of DH.

${ }^{7}$ For a taste of some of this literature see Rynard and Shugarman (eds.) 2000. Part 2 of the book offers seven essays that explicitly reject the very idea of $\mathrm{DH}$.

${ }^{8}$ Anscombe 1981:39-40 maintained that anyone who even contemplated such scenarios demonstrated a corrupt mind.

${ }^{9}$ See Nussbaum 1986 chapters 1-3, where she argues that good persons can be morally compromised by circumstances beyond their control.

${ }^{10}$ For a number of differing accounts see Hollis 1982, Stocker 2000, Walzer 1973, and de Wijze 1994. I seek to outline a generic account of DH. Tillyris 2015 and 2016, rejects this 'standard account' arguing it is too 'static' and incorrectly views the conflict between private morality and political duties as a stark but rare problem facing politicians in their roles qua politician. In its place Tillyris offers a 'the dynamic account', which he argues better captures the continual and unavoidable clash between morality and politics.

${ }^{11}$ See Hampshire 1989, Nagel 1978, Thompson1987, and Gowans 1994.

${ }^{12}$ Machiavelli 1950: 139.

${ }^{13}$ Hollis 1982: 388.

${ }^{14}$ For an extended discussion of this position, see Hampshire 1978.

15 See Walzer 1973, Nagel 1978 and Nielsen 2000.

${ }^{16}$ See Walzer 1973: 166-168. The 'Ticking Bomb Scenario' has been subject to much criticism as a dangerously misleading thought experiment that relies on unrealistic and erroneous key assumptions. For a response to these criticisms and an account of why such thought experiments are useful in moral theory see Beck and de Wijze 2015.

${ }^{17}$ The use of 'threshold deontology' or 'rule utilitarianism' do not resolve this tension as they both fail to acknowledge the tragic dimension of these conflicts and the moral residue that results. For a useful account of threshold deontology see Alexander2000. For a comprehensive overview of rule consequentialism see Hooker 2016.

18 See Hampshire 1989, Williams 1981 and Berlin 2003.

19 This way of approaching the DH issue is pursued by Stocker 2000: chapter 1.

${ }^{20}$ I have explored in some detail the necessary and sufficient conditions for DH in de Wijze 1994, 1996 and 2005.

${ }^{21} \mathrm{DH}$ theorists focus on the tragic element as they are acutely aware that justifying wrongdoing leads to the view that no wrong was committed. Arendt 2003:35-36 succinctly captures this concern. 'If you are confronted with two evils, thus the argument runs, it is your duty to opt for the lesser one whereas it is irresponsible to refuse to choose altogether . . . The weakness of the argument has always been that those who choose the lesser evil forget very quickly that they chose evil'.

22 Coady 1990: 263 refers to the different DH situations as those that involve 'crimes' (murder, torture), 'misdemeanours' (public lies, broken promises) and 'discomforts' (manipulations and necessary disowning). McDonald 2000; 194-196 refers to a distinction between 'bloody' and 'dirty' hands. The former involve assault murder and even genocide. The latter involve cases of fraud, dishonesty and insincerity.

${ }^{23}$ It is helpful to contrast DH actions with those that are moral and immoral along five dimensions. These comparisons are set out in the table below.

\begin{tabular}{|l|l|l|l|l|}
\hline & Action Justified & Agent Morally Polluted & Agent has appropriate moral motivation & Post action moral sentiment \\
\hline Moral action & Yes & No & Yes & Pride, satisfaction \\
\hline Immoral actions & No & Yes & No & Guilt, remorse \\
\hline DH action & Yes & Yes & Yes & Tragic-Remorse, satisfaction. \\
\hline
\end{tabular}

${ }^{24}$ Thompson 1987: 11.

${ }^{25}$ I intentionally leave the age at which a citizen is eligible to vote unspecified. I also leave aside issues of 'competence' here. These and other issues may differ from one democratic society to another.

${ }^{26}$ I have examined this fiduciary relationship at length in de Wijze 2003. If democratic politicians continually and consistently fail to act with the consent of citizens or deliberately act contrary to their mandate, they undermine the very moral rationale of the democratic process. 
${ }^{27}$ Shugarman 2000: 233, for example, claims that a participatory democratic model calls for elected leaders to exhibit transparency and accountability to citizens on an ongoing basis rather than every 5 years when facing elections. The latter he refers to as the 'elitist view' and the tone of his analysis makes it clear he thinks this approach to accountability is morally deficient and inferior to his participatory model.

${ }^{28}$ See Shugarman 2000 and Sutherland 2000.

${ }^{29}$ See Thompson 1987, Mendus 2009, Bellamy 2010, and Archard 2013.

${ }^{30}$ The concern about the problem of DH is not a recent phenomenon. Parrish 2007, argues that the from Augustine's ethics to Adam Smith's invocation of an Invisible Hand, their concerns were motivated in large part due to the problem of DH in public life even though they did not characterise the problem in these terms.

${ }^{31}$ See Sartre 1971; Camus 2006; and Brecht 1977.

${ }^{32}$ Parrish 2007: 15 and Shklar 1984: 242-243 both highlight this concern as one that has been largely absent from the DH literature.

${ }^{33}$ Shugarman 2000: 240. Shugarman specifically refers to Walzer's example of making a deal with corrupt ward bosses in order to win an election. This is vote rigging and inimical to proper democratic governance.

${ }^{34}$ Sutherland 2000: 223 forcefully makes this point and it is endorsed by Shugarman 2000.

35 See Bok 1999: 180-1.

${ }^{36}$ The rejection of DDH need not entail the rejection of DH as a possibility in private life or in nondemocratic forms of governance.

${ }^{37}$ See Sutherland 2000 and Shugarman 2000. Also sympathetic to this view are Coady 2008 and McDonald 2000.

${ }^{38}$ Sutherland 2000: 223.

${ }^{39}$ Sutherland 2000: 208 and Shugarman 2000: 230.

${ }^{40}$ To hold this view is to commit the fallacy of composition.

${ }^{41} \mathrm{DH}$ scenarios are more commonplace if we accept that deception and/or manipulation are core to any form of negotiation and compromise. Fortunately, severe cases of DH in politics, such as authorising targeted killings, or facing a ticking-bomb scenario, are very rare.

${ }^{42}$ Shugarman 2000: 231. He refers to DH advocates as 'moral Machiavellians' to distinguish them from the commonly held view that Machiavellians reject all talk of morality.

${ }^{43}$ Shugarman 2000: 232. Shugarman champions a deliberative model of democracy where all political problems are resolved by persuasion and deliberation. He rejects what he refers to as an elitist view with a restrictive understanding of the nature of citizenship and the relationship between politicians and citizens. However, to insist that democracy must take a deliberative form is to be far too prescriptive and glosses over the many problems with this approach. For a critique of Shugarman's deliberative model see Sanders 1997.

${ }^{44}$ Hampshire 1989: 170.

${ }^{45}$ See Sutherland 2000: 223. What is particularly puzzling about Shugarman's and Sutherland's views is that they do acknowledge that politics can throw up situations that require immoral and drastic action. Shugarman admits that there are cases of what he calls 'defensible DH' in extreme situations 'when democracy is denied, or democratic processes are subverted, or when it is a matter of self-defence or the defence of others under attack, or when all other avenues have been exhausted - but only then'. Given this list, Shugarman has no problems with DDH. His real concern is with its misuse and abuse by unscrupulous politicians. Sutherland 2000: 233 also admits that conflicts arise which make democratic politics a problem. However, she equivocates here and insists that this is where political institutions matter and we must engage the processes of a democratic society. It is not clear if she thinks that 'engaging democratic society' would be effective in every situation.

${ }^{46}$ See Gardner 2007.

${ }^{47}$ See Kutz 2007: 289.

${ }^{48}$ See Lepora and Goodin 2013: chapter 3 for an excellent analysis of this aspect of complicity.

${ }^{49}$ See Farmer 2007 who argues that complicity is possible without causality.

${ }^{50}$ I assume here that both citizens who are children, or adults denied the right to participate in the political process, are exempt from complicity. 
${ }^{51}$ As made clear by Burke 1774, in his 'Speech to the Electors of Bristol', politicians in a democracy are representatives and not delegates. As he puts it: 'Your representative owes you, not his industry only, but his judgment; and he betrays, instead of serving you, if he sacrifices it to your opinion.'

${ }^{52}$ This is the case even if we assume we are dealing with an honest politician who is not seeking to obfuscate the issue and dodge responsibility.

${ }^{53}$ Pasternak 2011. Also, see Beerbohm 2012: chapter 9 for a wide-ranging examination of democratic complicity.

${ }^{54}$ See Pasternak 2011: 122.

${ }^{55}$ See Beerbohm 2012: 10.

${ }^{56}$ Beerbohm 2012: 250.

${ }^{57}$ See Brecher 2007: 87-88 who explicitly rejects this claim. He argues that some immoral means, such as torture, are never justified even in cases of supreme emergency.

${ }^{58}$ For a detailed account of how tragic remorse differs from remorse, regret and agent-regret see de Wijze 2005.

${ }^{59}$ See Yeo 2000 for the different reasons for political secrecy.

${ }^{60}$ See Haydar \& Øverland 2014; Pasternak 2014; and Butt 2007 for accounts of the normative implications of benefiting from injustices.

${ }^{61}$ Archard 2013: 781-783

${ }^{62}$ Archard 2013: 782.

${ }^{63}$ Archard 2013: 784.

${ }^{64}$ See Bellamy 2010: 424. Bellamy points with the phenomenon of dirty hands ' we have the two aspects of real politics that liberal idealists tend to ignore - the uses of violence, on the one hand, and the need for dissimulation, on the other... Thus, a democratic Prince may have dirty hands, but must wear clean gloves.'

${ }^{65}$ Newey 1997:112 goes further arguing that in certain circumstances, political lies in a democracy are not only justified but also obligatory. Politicians in a democratic society have an obligation to lie to citizens who have 'a legitimate expectation that they be lied to.'

${ }^{66}$ For a more analysis of how politicians could be retrospectively held accountable for their DDH, see de Wijze 2003: 40-41. Also, see Thompson 1993:377 for his notion of 'mediated corruption', which refers to a politician's political rather than personal gains. While the method of achieving this benefit is improper (involves an immoral action), this is not the case with the benefits citizens receive.

Furthermore, the motives for obtaining this benefit are not corrupt but based on seeking the public good. If a politician can reasonably demonstrate that she is guilty of mediated corruption, this would allow for a retrospective endorsement of her actions by the public.

${ }^{67}$ For a detailed analysis of whether to punish those who dirty their hands, see de Wijze 2013.

${ }^{68} \mathrm{I}$ am indebted to Jeremy Barris, Eve Garrard and Daniel de Wijze for extensive comments on an earlier draft. 